\title{
Achieving near Zero Energy Building in Albania: An Approach for the Retrofit of a Public-School Building
}

\author{
Lorenzo Belussi ${ }^{1,{ }^{*}}$, Ludovico Danza ${ }^{1}$, Matteo Ghellere ${ }^{1}$, Italo Meroni ${ }^{1}$, Francesco \\ Salamone ${ }^{1}$, Arben Shtylla ${ }^{2}$, Etleva Dobjani ${ }^{2}$ and Saimir Shtylla ${ }^{2}$ \\ ${ }^{1}$ ITC-CNR, via Lombardia 49, 20098 San Giuliano Milanese (Mi), Italy \\ ${ }^{2}$ Polis University, Department of Applied Research, Rr. Bylis 12, Autostrada Tiranë-Durrës, Km 5, \\ 1051, Tirana, Albania
}

\begin{abstract}
Since its introduction in 2010, the nearly Zero Energy Building (nZEB) concept has known a large diffusion in European countries. Albania, an aspiring candidate country to join the European Union EU, is paving the way towards its introduction by transposing EU directives in the fields of energy efficiency into the national legislation. Most of the national building stock includes buildings with low thermal and energy performance but with high refurbishment potential, too. The country can become an important contributor in the EU decarbonization strategy due to the high percentage of electricity produced by hydropower stations, making it one of the least carbon-intensity countries in the electricity production point of view. The article focuses on the evaluation of the energy performance of an existing school located in Tirana and the potentialities to reach the nZEB target, analysing both the suitable technological solutions and the energy market situation. The Primary Energy Factors PEF for the local electricity market are estimated referring to statistical data and in comparison, with neighbouring countries, Italy and Greece, in order to investigate the potential of the achievement of the nZEB target in Albania.
\end{abstract}

\section{Introduction}

The paper presents the outcomes of the bilateral research ${ }^{\dagger}$ between ITC-CNR (Italy) and Polis University (Albania), focused on the identification of retrofit solutions leading to a best practice level of nZEB in Albania, relying on local and affordable technical solutions. The reduction of Greenhouse Gas Emissions (GHG) and consumption of energy resources is still a challenge in every country's agenda [1]. The improvement of the energy efficiency of the building sector offers a great chance for a low-carbon future, considering that

\footnotetext{
* Corresponding author: belussi@itc.cnr.it

$\dagger$ This project is financed by the Agency for Research, Technology and Innovation (ARTI) - [ALB] Ky projekt u mundësua falë financimit të Agjensisë Kombëtare të Kërkimit Shkencor dhe Inovacionit (AKKSHI)
} 
buildings are responsible for $35-40 \%$ of the total energy consumption worldwide [2]. The potential savings in terms of energy consumption in the sector are huge, even though a large part of the building stock has been built when attention towards energy efficiency was very limited or absent. This goal is possible by introducing and implementing the ZeroEnergy Building (ZEB) concept, especially in the retrofit of public buildings [3]. The European Union EU has paid particular attention and invested lots of efforts for this issue in the last decades leading to the development of many successful case studies across the EU [4]. The nearly Zero Energy Building (nZEB) concept which engaged scientific community, professionals and construction companies in the identification of innovative and sustainable solutions, has triggered an important stimulus towards the reduction of GHG and energy consumption. Nowadays, all EU countries have defined in their national legislations the energy requirements for nZEBs, although different degrees of implementation are observed among them [5]. Each Member State (MS) has defined a set of requirements for new and existing buildings regarding: (i) minimum thermal transmittance (U-value) requirements for opaque and transparent building components (walls, roofs, floors, windows, etc.); (ii) global primary energy (PE) consumption; (iii) energy efficiency and performance of heating, cooling, ventilation and domestic hot water (DHW) systems; and (iv) ratio of energy produced by renewable energy sources (RES). Moreover, each MS has defined its own primary energy factors (PEF) for each energy carrier for the calculation of the PE consumption, based on the characteristics of the national energy production and network and political roadmaps. It has led to the creation a diversified panorama across Europe because of the differences in climatic conditions, building market progress, energy mix and network, policies. [6] and [7] summarize the requirements defined by each MS in relation to the national climatic contexts. Regarding the PEFs, it connects the final energy and PE, where the last one is the source that involves only the extraction or capture before the embodied energy is converted into heat or mechanical work. PEFs influence the accounting of specific targets as use of renewable energy sources [8] and consequently they can affect the calculation of PE of buildings and the achievement of the nZEB target [9]. Unlike the MS, the situation in the aspiring candidate countries is even more fragmented $[10,11]$. The adoption and implementation of EU Directives in the field of energy efficiency, as in the case of the Energy Performance Building Directive (EPBD) into the national legislations, are mandatory to join the EU but so far their implementation has not been easy. The national framework on energy efficiency in these countries is still in progress because the absence of the further legislative acts, that could also unlock the diffusion of nZEB. The article analyses the situation in Albania, focusing on the identification of retrofit solutions leading to a best practice level of nZEB in this country. In recent years, Albania has transposed two important EU directives into its legislation, highlighting its commitment to increase the energy efficiency of its building stock. Indeed, Law nr. 124/2015* (on Energy Efficiency) and Law nr. 116/2016 ${ }^{\S}$ (on Energy Performance of Buildings) are the transposition of the Directives 2010/31/EU and 2012/27/EU, respectively. In July 2020, an important step was made with the approval of Law nr. 537/2020** defining the minimum requirements for the energy performance of existing and new buildings, in line with the EPBD guidelines but it is still early to measure the impact. A recent analysis on the Albanian residential building stock [12], identified in the poor-energy performance buildings' envelopes and wide use of wood stove for space heating as main characteristics, also common for public school buildings. In Albania, the

\footnotetext{
* [ALB] Ligji Nr. 124/2015 "Për efiçencën e energjisë"

$\S$ [ALB] Ligji Nr. 116/2016 "Për performancën e energjisë së ndërtesave"

** [ALB] Ligji Nr. 537/2020 "Për miratimin e kërkesave minimale të performancës së energjisë së ndërtesave dhe të elementeve të ndërtesave"
} 
public-school buildings' stock includes standard typologies (known as Shkolla tip ${ }^{\dagger \dagger}$ ) of various capacities and standard building technology distributed in the territory according to the demand during Socialism. Unfortunately, the conditions of these buildings built before the 90s are not the best in terms energy efficiency although some of them have undergone to partial or consistent retrofit interventions when no energy efficiency policy was in power. The refurbishment of existing school buildings in a nZEB perspective can pave the way towards the increase of energy efficiency of the national building stock. Not less relevant is the opportunity to achieve a faster decarbonization of the schools' building stock and reduction of the country's carbon intensity from an electricity demand point of view because in Albania the national electricity demand is fulfilled in high percentage from hydropower stations [13]. Moving from these premises, the article focuses on the evaluation of the energy performance of an existing school building located in Tirana and the potentials to reach the nZEB target, analyzing both suitable technological solutions and the energy market situation. The PEFs estimated for Albanian electricity market are based on statistical data and comparison with neighboring countries (Italy and Greece) where the directives on energy efficiency and renewable energy are fully actuated, in order to investigate the potential in reaching nZEB target in Albania.

\section{METHODOLOGY AND AIM OF THE STUDY}

\subsection{Climatic context and reference building}

Albania is distinguished for Mediterranean climate in the coasts with hot and dry summers whereas winters are mild and wet. It is classified as "Hot-summer Mediterranean climate" by the Köppen-Geiger system [14], with an average annual temperature of $14.8^{\circ} \mathrm{C}\left(7^{\circ} \mathrm{C}\right.$ in winter and $24{ }^{\circ} \mathrm{C}$ in summer). The country in divided into three climate zones where zone A (Heating Degree Days, HDD $<1500)$ is the hottest, zone B $(1501<\mathrm{HDD}<2500)$ and zone $\mathrm{C}(\mathrm{HDD}>2500)$ as the coldest one (see Figure 1). The municipality of Tirana is divided between the climate zone A (West) and climate zone B (East). The reference building is in climatic zone A, according to the Albanian climate zoning [12]. The Typical Meteorological Year (TMY) derives from [15] and is referred to the period 2004-2018.

The reference building is a typical example of the approach adopted in the design and construction of school buildings in the country during Socialism. After being designed and approved in the state design offices, the construction of these specific school typologies occurred by considering considerations the sites climate and orientation. Indeed, it is a 12classrooms school building typology $\$$ (see Figure 2 ) located in the outskirts of Tirana (the country's capital), in climate zone A, that according to design specification consulted in the National Technical Archive (NTA) was built in $1983^{\S \S}$. The building hosts 420 pupils attending the primary and lower secondary cycle. With an East-West orientation, the building has changed in the recent years its volume in to incorporate some functions that were not expected inside the building into the original design (see Figure 1), thus resulting with an increase of the volume and floor area whose values are listed Table 1 among other geometrical characteristics of the reference building.

\footnotetext{
${ }^{\dagger}$ [ALB] Standard Typologies of schools from 1 to 4 storey high for specific context (urban, suburban and rural).

$\$$ Technical name of the typological project at the Central National Technical Archive: "Shkolle 8vjeçare me 12 dhe 8 klasa 73.6" (8-year cycle school with 12 and 8 classrooms 73.6)

$\S \S$ Referring site plan file at the Central National Technical Archive: "Shkollë në fshatin Bregu i

Lumit dt 10.05.1983" (School in the village of Bregu i Lumit dated 10.05.1983)
} 
Table 1. Geometrical dimension of the reference building

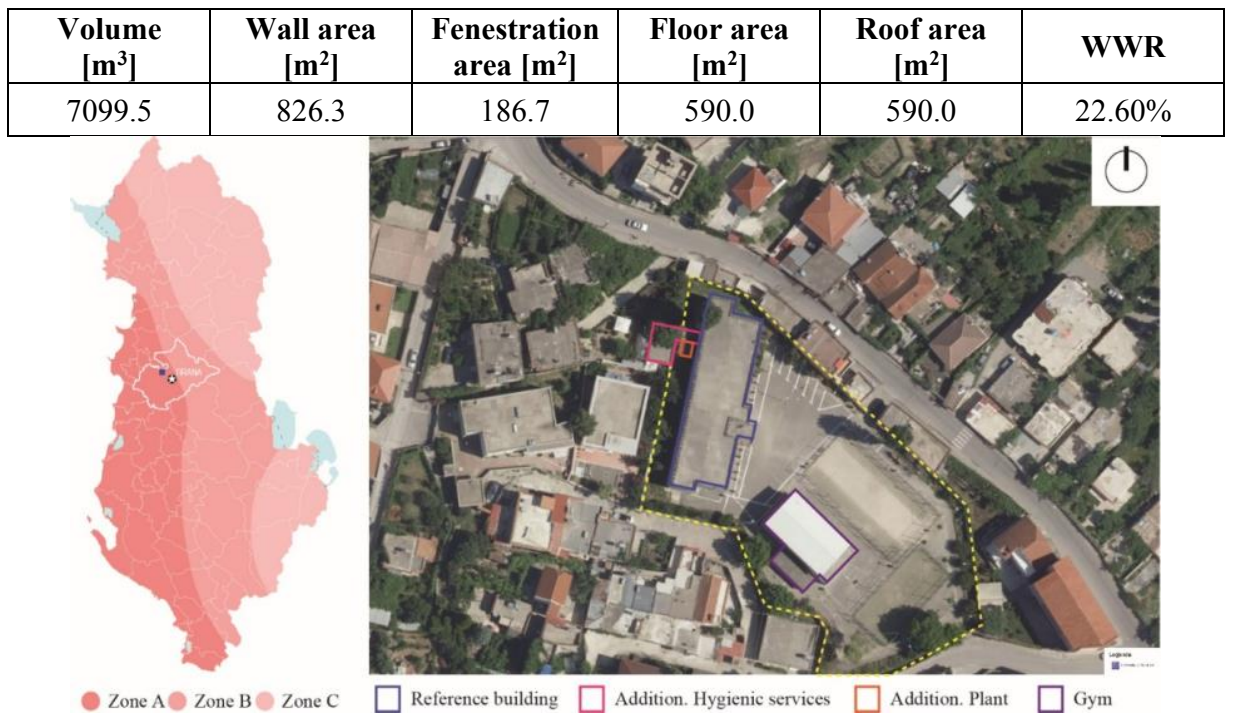

Fig. 1. Albania Climate context (left - source: the authors) and site map of the school building (rightsource: asig.al)
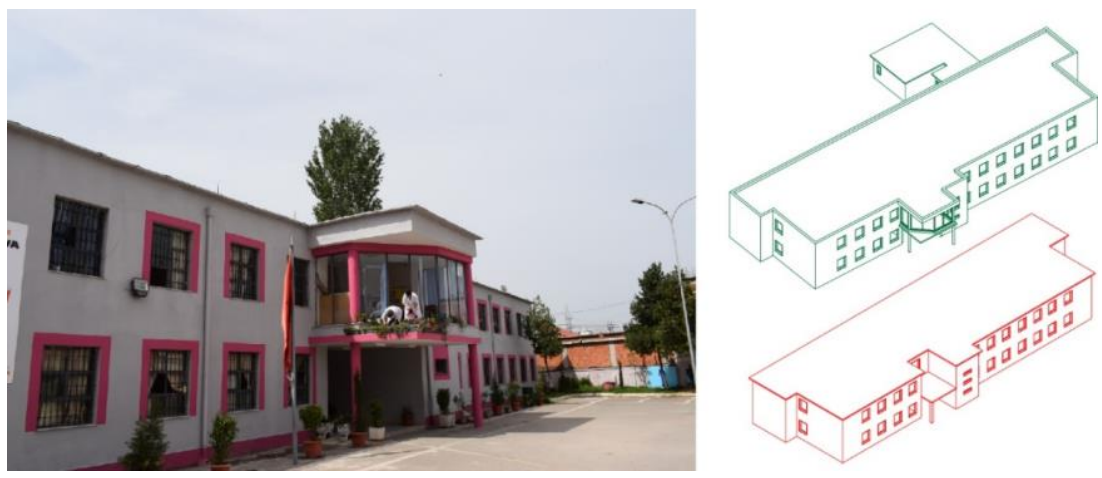

Fig. 2. Main facade of the school and comparison current situation (green) and original design (red) (source: the authors)

The evaluation of the energy performance of the building was performed with the Building Energy Modeling (BEM) software Openstudio 3.0.0 and EnergyPlus 9.4. The simulation was performed under the climatic condition of Tirana, before and after the application of the refurbishment measures. The weighted energy balance is calculated according to international standard EN ISO 52000, using primary energy factors as weighted factors:

$$
E_{w e}=E_{w e, d e l}-E_{w e, \exp }
$$

Where, $E_{\text {we,del }}$ is the weighted delivered energy and $E_{w e, e x p}$ is the weighted exported energy. The time schedules for services, occupancy and utilization are provided by ISO 18523-1. Also, there will be performed simulations of the refurbishment scenarios of the school in countries with similar climatic conditions as Italy and Greece in order to identify the difference in PE consumption due to the characteristics of the energy market. The simulations will occur applying the minimum requirements provided by laws of the respective countries on the thermal and energy performance for the refurbishment of 
existing buildings, obviously for the climatic contexts similar to the Albanian one. Indeed, the refurbishment scenario will occur under the climate conditions of the cities Foggia (Italy) and Thessaloniki (Greece), chosen after the analysis of each TMY. Heating PE consumption is normalized using the Heating Degree Days (HDD) for each location based on the data provided by local TMYs.

$$
H D D=\Sigma\left(T_{\text {base }}-T_{i}\right)^{+}
$$

Where, $T_{\text {base }}$ is the reference temperature and $T_{i}$ is the mean daily temperature for each day. The symbol "+" indicates that the sum accounts only positive value of the difference between brackets. Finally, the share of renewable energy is accounted through the Renewable Energy Ratio (RER), as the ratio between renewable PE consumption, $\mathrm{E}_{\mathrm{P}, \mathrm{ren}}$, and total $\mathrm{PE}$ consumption, $\mathrm{E}_{\mathrm{P}, \mathrm{tot}}$, as follow:

$$
R E R=E_{P, r e n} / E_{P, t o t}
$$

In this study, any amount of energy exported to the grid when there is overproduction is computed considering the same weighting factor for the corresponding delivered energy (Step A of ISO 52000-1).

\subsection{Building technology}

Table 2. Current situation-Thermal performances of opaque building components

\begin{tabular}{|c|l|c|c|c|}
\hline Component & \multicolumn{1}{|c|}{ Layer } & $\begin{array}{c}\text { Thickness } \\
(\mathbf{c m})\end{array}$ & $\begin{array}{c}\text { Conductivity } \\
(\mathbf{W} / \mathbf{m K})\end{array}$ & $\begin{array}{c}\text { U-Value } \\
\left(\mathbf{W} / \mathbf{m}^{2} \mathbf{K}\right)\end{array}$ \\
\hline \multirow{4}{*}{$\begin{array}{c}\text { External } \\
\text { wall }\end{array}$} & External plaster & 3 & 0.90 & \multirow{3}{*}{1.26} \\
\cline { 2 - 4 } & Brick & 25 & 0.44 & \\
\cline { 2 - 4 } & Internal plaster & 2 & 0.90 & \\
\hline \multirow{4}{*}{$\begin{array}{c}\text { Ground } \\
\text { floor }\end{array}$} & Tiles ceramic tiles & 2 & 1.00 & \multirow{3}{*}{2.71} \\
\cline { 2 - 4 } & Concrete substrate & 2 & 0.90 & \\
\cline { 2 - 4 } & Waterproof & 1 & 0.35 & \multirow{2}{*}{0.48} \\
\cline { 2 - 4 } & Reinforced Concrete & 8 & 2.00 & \\
\cline { 2 - 4 } & Gravel/Stone & 15 & 1.70 & \\
\hline \multirow{4}{*}{ Roof } & Waterproof membrane & 1 & 0.26 & \\
\cline { 2 - 4 } & Polystyrene insulation & 5 & 0.04 & \\
\cline { 2 - 4 } & Concrete floor & 11.5 & 0.9 & \\
\cline { 2 - 4 } & $\begin{array}{l}\text { Reinforced concrete and } \\
\text { hollow tiles mixed floor }\end{array}$ & 24 & 0.46 & \\
\hline
\end{tabular}

As mentioned previously, the building is a standard school building typology common for rural areas during Socialism and reflects the standard building solutions adopted in the construction of school buildings in Albania for the 1945-1990 period. In the recent years, the most important intervention performed in to improve its energy performance is the insulation of the roof with $0.04 \mathrm{~m}$ of polystyrene layer and a waterproof finish on top. As illustrated in Table 2, where are described the properties of the layers of the opaque components, it emerges that the external load-bearing masonry walls are uninsulated. The ground floor slab is also uninsulated and includes a $0.08 \mathrm{~m}$ thick reinforced-concrete layer, waterproofing layer with tiles finish on top. In order to avoid eventual flooding, the ground floor slab lays on gravel base that elevates it a couple of centimeters from the ground. Regarding the transparent components, in terms of layout and technology, the current 
windows are single glazed with aluminum frame. Their thermal performance is calculated according to the technical standard EN 10077-1, with U-values ranging between 6.0 and 6.8 $\mathrm{W} / \mathrm{m}^{2} \mathrm{~K}$ depending on the dimensions, shape and structure.

A fuel-based heating system is operative with radiators as terminals in each classroom. It is supplied by a two-stage plant with an installed power ranging between $178-391 \mathrm{~kW}$ and used only for heating and two separate boilers guarantee the production of Domestic Hot Water (DHW).

\subsection{Retrofit interventions}

Since July 2020, thanks to the approval of Law nr. 537/2020, there were defined the thermal and energy performance requirements for new and existing building envelope components and the requirements for the nZEB label. Unlike MS where U-values differ in relation of the climate zone, the mandatory U-value for envelope's components are the same regardless the climatic zones, as well the minimum energy efficiency of technological systems (heating, cooling, ventilation and DHW). The benchmark of PE consumption is equal to $50 \mathrm{kWh} / \mathrm{m}^{2} \mathrm{y}$. The PE consumption of a building is calculated by multiplying the benchmark with the deriving coefficient from the ratio between the energy demand of the analysed building with the reference one (similar morphological, geometric and functional characteristics with the current one defined on the basis of the national building stock). To obtain the nZEB label, the energy consumption should be lower than $50 \%$ than the reference building's consume or produce $50 \%$ of its energy demand from renewable sources, without any specification on the service. Starting from these considerations and the buildings characteristics, the proposed refurbishment interventions are in compliance with the national requirements that existing buildings to achieve nZEB. In Table 3, there are summarised all the requirements for the refurbishment of existing building envelope's components for Albania, Italy and Greece in relation to the climate zones. The external walls expect the external thermal insulation composite system (ETICS) with expanded polystyrene (EPS). In the roof, the current insulation is removed and replaced with a

Table 3. Minimum U-values for existing buildings in Albania [16], Italy [17], Greece [18]

\begin{tabular}{|c|c|c|c|c|c|c|c|c|c|c|c|c|c|}
\hline & \multicolumn{3}{|c|}{ Albania } & \multicolumn{6}{|c|}{ Italy } & \multicolumn{4}{|c|}{ Greece } \\
\hline $\begin{array}{c}\text { Climate } \\
\text { Zone }\end{array}$ & A & B & $\mathrm{C}$ & A & B & $\mathrm{C}$ & D & E & $\mathrm{F}$ & A & B & $\mathrm{C}$ & D \\
\hline HDD & $\frac{8}{8}$ & $\begin{array}{l}8 \\
0 \\
n \\
1 \\
0 \\
0 \\
-1\end{array}$ & $\begin{array}{l}\overline{0} \\
\stackrel{n}{\wedge}\end{array}$ & \& & $\begin{array}{l}8 \\
8 \\
\cdots \\
\stackrel{1}{0}\end{array}$ & $\begin{array}{l}\stackrel{8}{+} \\
\stackrel{1}{\circ} \\
\stackrel{\circ}{\circ}\end{array}$ & $\begin{array}{l}8 \\
\stackrel{1}{1} \\
\stackrel{+}{+}\end{array}$ & 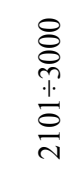 & $\underset{\AA}{\wedge}$ & $\frac{8}{8}$ & $\begin{array}{l}8 \\
\stackrel{0}{1} \\
\stackrel{1}{8} \\
8\end{array}$ & 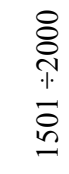 & 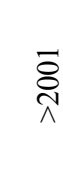 \\
\hline $\begin{array}{c}\text { External } \\
\text { walls }\end{array}$ & \multicolumn{3}{|c|}{0.40} & \multicolumn{2}{|c|}{0.40} & 0.36 & 0.32 & 0.28 & 0.26 & 0.60 & 0.50 & 0.45 & 0.40 \\
\hline $\begin{array}{c}\text { Ground } \\
\text { floor slab }\end{array}$ & \multicolumn{3}{|c|}{0.45} & \multicolumn{2}{|c|}{0.42} & 0.38 & 0.32 & 0.29 & 0.28 & 1.50 & 1.00 & 0.80 & 0.70 \\
\hline Roof & \multicolumn{3}{|c|}{0.35} & \multicolumn{3}{|c|}{0.32} & 0.26 & 0.24 & 0.22 & 0.50 & 0.45 & 0.40 & 0.35 \\
\hline Windows & \multicolumn{3}{|c|}{2.20} & & & 2.00 & 1.80 & 1.40 & 1.00 & 3.20 & 3.00 & 2.80 & 2.60 \\
\hline Note & \multicolumn{3}{|c|}{$\begin{array}{c}\text { HDD reference } \\
\text { temperature: } \\
17.5^{\circ} \mathrm{C}\end{array}$} & \multicolumn{6}{|c|}{ HDD reference temperature: $20^{\circ} \mathrm{C}$} & \multicolumn{4}{|c|}{$\begin{array}{l}\text { HDD reference } \\
\text { temperature: } 18^{\circ} \mathrm{C}\end{array}$} \\
\hline
\end{tabular}


Table 4. Refurbishment interventions

\begin{tabular}{|c|c|c|c|c|}
\hline Country & \multicolumn{2}{|c|}{ Components } & Performance & Refurbishment intervention \\
\hline \multirow{5}{*}{ Albania } & \multirow{4}{*}{$\begin{array}{l}\text { Building } \\
\text { envelope }\end{array}$} & $\begin{array}{l}\text { External } \\
\text { walls }\end{array}$ & $\begin{array}{l}\mathrm{U}=0.40 \\
\mathrm{~W} / \mathrm{m}^{2} \mathrm{~K}\end{array}$ & $\begin{array}{l}8 \mathrm{~cm} \text { thick Expanded polystyrene } \\
(\mathrm{EPS}), \lambda=0.045 \mathrm{~W} / \mathrm{mK} \text { and } 2 \mathrm{~cm} \\
\text { external plaster finish }\end{array}$ \\
\hline & & Roofs & $\begin{array}{l}\mathrm{U}=0.45 \\
\mathrm{~W} / \mathrm{m}^{2} \mathrm{~K}\end{array}$ & $\begin{array}{l}8 \mathrm{~cm} \text { thick Expanded polystyrene } \\
(\mathrm{EPS}), \lambda=0.045 \mathrm{~W} / \mathrm{mK} \text { and } 7 \mathrm{~cm} \\
\text { gravel finish }\end{array}$ \\
\hline & & $\begin{array}{l}\text { Ground } \\
\text { floor }\end{array}$ & $\begin{array}{l}\mathrm{U}=0.35 \\
\mathrm{~W} / \mathrm{m}^{2} \mathrm{~K}\end{array}$ & $\begin{array}{l}8 \mathrm{~cm} \text { thick Cellular glass foam, } \lambda= \\
0,045 \mathrm{~W} / \mathrm{mK} \text { and } 2 \mathrm{~cm} \text { and tiles finish }\end{array}$ \\
\hline & & Windows & $\begin{array}{l}\mathrm{U}=2.20 \\
\mathrm{~W} / \mathrm{m}^{2} \mathrm{~K}\end{array}$ & $\begin{array}{l}\text { Low emissivity double-glazed with } 16 \\
\text { mm gap in between and metal frame } \\
\text { with thermal break }\end{array}$ \\
\hline & $\begin{array}{c}\text { Heating } \\
\text { system }\end{array}$ & GSHP & $\mathrm{SPF}=3.00$ & Ground source heat pump for heating \\
\hline \multirow{5}{*}{$\begin{array}{c}\text { Italy } \\
\text { Zone D }\end{array}$} & \multirow{4}{*}{$\begin{array}{l}\text { Building } \\
\text { envelope }\end{array}$} & $\begin{array}{l}\text { External } \\
\text { walls }\end{array}$ & $\begin{array}{l}\mathrm{U}=0.31 \\
\mathrm{~W} / \mathrm{m}^{2} \mathrm{~K}\end{array}$ & $\begin{array}{l}11 \mathrm{~cm} \text { thick Expanded polystyrene } \\
(\text { EPS), } \lambda=0.045 \mathrm{~W} / \mathrm{mK} \text { and } 2 \mathrm{~cm} \\
\text { external plaster finish }\end{array}$ \\
\hline & & Roofs & $\begin{array}{l}\mathrm{U}=0.25 \\
\mathrm{~W} / \mathrm{m}^{2} \mathrm{~K}\end{array}$ & $\begin{array}{l}14 \mathrm{~cm} \text { thick Expanded polystyrene } \\
\text { (EPS), } \lambda=0.045 \mathrm{~W} / \mathrm{mK} \text { and } 7 \mathrm{~cm} \\
\text { gravel finish }\end{array}$ \\
\hline & & $\begin{array}{l}\text { Ground } \\
\text { floor }\end{array}$ & $\begin{array}{l}\mathrm{U}=0.31 \\
\mathrm{~W} / \mathrm{m}^{2} \mathrm{~K}\end{array}$ & $\begin{array}{l}13 \mathrm{~cm} \text { thick Cellular glass foam, } \lambda= \\
0,045 \mathrm{~W} / \mathrm{mK} \text { and } 2 \mathrm{~cm} \text { tiles finish }\end{array}$ \\
\hline & & Windows & $\begin{array}{l}\mathrm{U}=1.80 \\
\mathrm{~W} / \mathrm{m}^{2} \mathrm{~K}\end{array}$ & $\begin{array}{l}\text { Low emissivity triple-glazed with } 6 \\
\text { mm gap in between and metal frame } \\
\text { with thermal break }\end{array}$ \\
\hline & $\begin{array}{c}\text { Heating } \\
\text { system }\end{array}$ & GSHP & $\mathrm{SPF}=3.00$ & Ground source heat pump for heating \\
\hline \multirow{5}{*}{$\begin{array}{l}\text { Greece } \\
\text { Zone C }\end{array}$} & \multirow{4}{*}{$\begin{array}{l}\text { Building } \\
\text { envelope }\end{array}$} & $\begin{array}{l}\text { External } \\
\text { walls }\end{array}$ & $\begin{array}{l}\mathrm{U}=0.42 \\
\mathrm{~W} / \mathrm{m}^{2} \mathrm{~K}\end{array}$ & $\begin{array}{l}7 \mathrm{~cm} \text { thick Expanded polystyrene } \\
\text { (EPS), } \lambda=0.045 \mathrm{~W} / \mathrm{mK} \text { and } 2 \mathrm{~cm} \\
\text { external plaster finish }\end{array}$ \\
\hline & & Roofs & $\begin{array}{l}\mathrm{U}=0.37 \\
\mathrm{~W} / \mathrm{m}^{2} \mathrm{~K}\end{array}$ & $\begin{array}{l}8 \mathrm{~cm} \text { thick Expanded polystyrene } \\
(\text { EPS), } \lambda=0.045 \mathrm{~W} / \mathrm{mK} \text { and } 7 \mathrm{~cm} \\
\text { gravel finish }\end{array}$ \\
\hline & & $\begin{array}{c}\text { Ground } \\
\text { floor }\end{array}$ & $\begin{array}{l}\mathrm{U}=0.70 \\
\mathrm{~W} / \mathrm{m}^{2} \mathrm{~K}\end{array}$ & $\begin{array}{l}5 \mathrm{~cm} \text { thick Cellular glass foam, } \lambda= \\
0,045 \mathrm{~W} / \mathrm{mK} \text { and } 2 \mathrm{~cm} \text { tiles finish }\end{array}$ \\
\hline & & Windows & $\begin{array}{l}\mathrm{U}=2.80 \\
\mathrm{~W} / \mathrm{m}^{2} \mathrm{~K}\end{array}$ & $\begin{array}{l}\text { Low emissivity double-glazed with } 6 \\
\text { mm gap in between and metal frame } \\
\text { with thermal break }\end{array}$ \\
\hline & $\begin{array}{c}\text { Heating } \\
\text { system }\end{array}$ & GSHP & $\mathrm{SPF}=3.00$ & Ground source heat pump for heating \\
\hline
\end{tabular}

new one in EPS and with gravel finish on top. The ground floor remains the most critical part, because its insulation implies the reduction of the classrooms' height, so the best solution is a new insulation layer in cellular glass foam. Windows are replaced with double glazed ones with thermal break metal frame. An electric ground source heat pump (GSHP) replaces the two-stage plant (heating) and the current boilers (Domestic Hot Water DHW). In the current analysis, cooling demand is not considered. The amount of energy from renewable energy sources related to the use of heat pump, $E_{\mathrm{RES}}$, is accounted according to Annex VII of Directive 2009/28/EC as follow:

$$
E_{R E S}=Q_{u s a b l e} \times(1-1 / S P F)
$$


where, $\mathrm{Q}_{\text {usable }}$ is the total heat delivered by heat pump and SPF is the average Seasonal Performance Factor. The refurbishment scenarios for Italy and Greece comply with the minimum requirements provided by the respective national laws in relation to the climate zone and the limits of refurbishment intervention, too. Even though the solutions adopted for the Albanian context will be the same for Italy and Greece, obviously the thickness of insulation materials adopted will be different, as well the windows' properties, due to the necessity to respect the national requirements of the thermal and energy performance that must be respected in refurbishment interventions. For the Italian scenario, the installation of a photovoltaic (PV) system is mandatory for the exploitation of renewable energy. Consequently, the installed PV peak power, $\mathrm{P}$, is calculated according to the Italian Legislative Decree 28/2011 as follow:

$$
P=(1 / k) \times S
$$

Where $\mathrm{k}$ is a coefficient equal to $50 \mathrm{~kW} / \mathrm{m}^{2}$ and $\mathrm{S}$ is the building's footprint. In Greece, there is not any limit or requirement concerned with the installation of PV order to reach the nZEB target (despite the use of RES is mandatory), so the installed peak power will be the same as for the Italian scenario. As described in Table 4, the refurbishment interventions in the three countries focus only in the building envelope and heating system, whereas the lighting is not included in the refurbishment.

\subsection{Primary energy factor calculation}

There are several approaches used for the calculation of PEFs for electricity $[19,20]$. The Zero Equivalent (ZE), the Direct Equivalent (DE) and the Physical Energy Content (PEC) are the most accepted accounting methods for non-combustible RES [21]. The ZE method accounts a PEF equal to 0 for all non-combustible RES in electricity generation. This method takes into account only non-renewable PEF. On the other hand, the DE method assigns a PEF value equal to 1 to all non-combustible RES. The PEC method considers PE before it is used for different purposes assigning it a value equal to 1 for all noncombustible RES. DE and PEC methods account the total PEF assuming a conversion efficiency factor $\mathrm{h}$ of $100 \%$. In Table 6 , there are listed the PEFs and the conversion efficiency for non-combustible renewable PEFs for the production of electricity. Considering that in Albania, most of the electricity demand is produced by hydropower stations, there are considered the data referred to this source. DE and PEC are equivalent with this source. PEF for electricity is calculated considering as useful energy the electricity produced by Albanian power plants and the imported energy from countries abroad.

Table 5. Non-combustible renewable PEF and efficiency, $\eta$ (from [24)

\begin{tabular}{|c|c|c|c|c|c|c|}
\hline \multirow{2}{*}{ Sources } & \multicolumn{3}{|c|}{ PEF } & \multicolumn{3}{c|}{$\eta$} \\
\cline { 2 - 7 } & ZE & DE & PEC & DE & ZE & DE \\
\hline Hydro & 0 & 1 & 1 & n.a. & $100 \%$ & $100 \%$ \\
\hline Wind & 0 & 1 & 1 & n.a. & $100 \%$ & $100 \%$ \\
\hline Solar (PV) & 0 & 1 & 1 & n.a & $100 \%$ & $100 \%$ \\
\hline Geothermal & 0 & 1 & 10 & n.a. & n.a. & $10 \%$ \\
\hline Nuclear & n.a. & 1 & 3 & n.a & $100 \%$ & $33 \%$ \\
\hline
\end{tabular}

The first step is the calculation of the net electricity demand, $\mathrm{Q}_{\mathrm{el}, \mathrm{dem}}$ :

$$
Q_{e l, d e m}=Q_{e l, g e n} x\left(1-Q_{l o s s^{-}} Q_{s e l f}\right)
$$


Where, $\mathrm{Q}_{\mathrm{el}, \mathrm{gen}}$ is the gross electricity production; $\mathrm{Q}_{\text {loss }}$ is the power transmission; and distribution losses and $\mathrm{Q}_{\text {self }}$ is the self-consumption of the hydropower plant. The average losses between 2016 and 2020 of the electricity networks amounted to $24 \%^{* * *}$. For the selfconsumption, it is adopted a value of $4 \%$, equal to the average value for EU countries [21]. The raw PE demand, QPED is calculated as:

$$
Q_{P E D}=\sum_{\text {fuel }}\left[\left(Q_{\text {el,gen }} \times P E F\right) / \eta\right]
$$

In the case of hydropower production, $\mathrm{QPED}_{\mathrm{PED}}$ and $\mathrm{Q}_{\mathrm{el}, \mathrm{gen}}$ are equivalent. Finally, the PEF for electricity, $\mathrm{PEF}_{\mathrm{el}}$ is calculated as:

$$
P E F_{e l}=Q_{P E D} / Q_{e l, d e m}
$$

In this procedure, the contribution of combined heat and power (CHP) production is neglected as long as electricity in the country is not generated with this technology. Using the data mentioned above for local electricity production, the global $\mathrm{PEF}_{\mathrm{el}}$ for Albania is equal to 1.39. The non-renewable PEF of hydropower plant is lower than $0.01[22,23]$. Considering the imported electricity with the PEF of ISO 52000, the total $\mathrm{PEF}_{\text {el }}$ for Albania is equal to 1.68 , with 0.44 related to non-renewable and 1.23 to renewable. For nonrenewable sources, the value provided by EN 52000 are assumed for Albanian energy market.

\section{RESULTS AND DISCUSSION}

The results of the simulations of the reference building in the current state revealed a total gas consumption of $208 \mathrm{GWh}$ and a total electric consumption of $78 \mathrm{GWh}$ (excluding equipment consumption where its contribution is intended as heat gain). By dividing these values by net conditioned area of the building, the corresponding specific delivered energy indicators are $181.8 \mathrm{kWh} / \mathrm{m}^{2} \mathrm{y}$ and $67.9 \mathrm{kWh} / \mathrm{m}^{2} \mathrm{y}$ respectively. As illustrated in Fig.3 (left), the gas consumption is the highest of the overall consumption due to the poor thermal and the energy performance of the building. In Fig. 3 (right) is mapped the breakdown of electricity consumption. Considering that the building is not equipped with any ventilation or cooling systems, therefore these services are not included in the analysis. The total PE consumption is equal to $314.0 \mathrm{kWh} / \mathrm{m}^{2} \mathrm{y}$, with an electricity share of $114.0 \mathrm{kWh} / \mathrm{m}^{2} \mathrm{y}$ and gas of $200.0 \mathrm{kWh} / \mathrm{m}^{2} \mathrm{y}$. The renewable PE consumption is $83.5 \mathrm{kWh} / \mathrm{m}^{2} \mathrm{y}$ and the nonrenewable $230.5 \mathrm{kWh} / \mathrm{m}^{2} \mathrm{y}$.
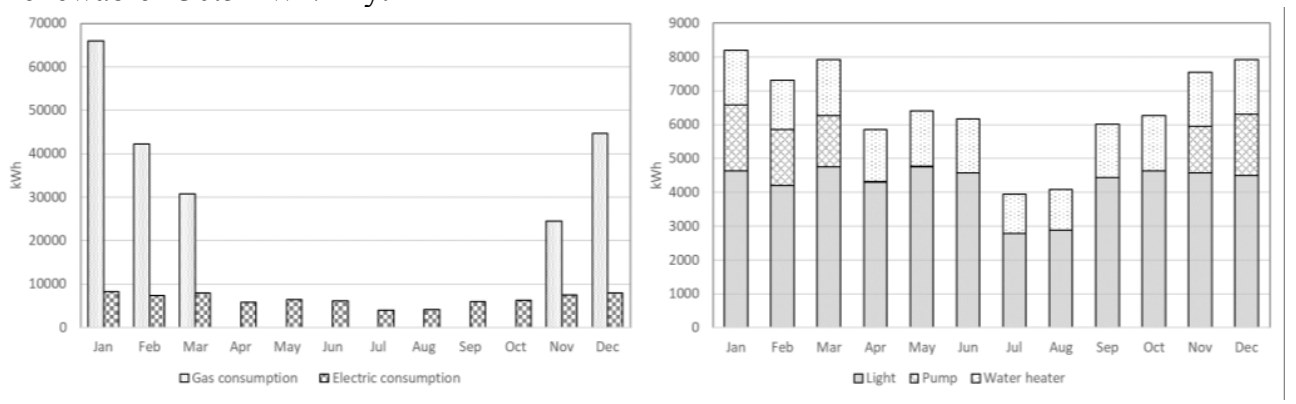

Fig. 3. Current reference building's situation - Monthly gas and electricity consumption (left) and breakdown of electricity consumption- (source: the author)

${ }^{* * *}$ Source $: \underline{\text { http://www.instat.gov.al/en/themes/environment-and-energy/energy }}$ 
The refurbishment intervention includes the installation of an ETICS in the envelope level and the installation of a GSHP at system level. Equipment consumption is not considered as long it is not accounted in total PE consumption by national laws. In Fig. 4, it is illustrated the comparison of the PE consumption of the reference building before and after the application of the refurbishment measures and the breakdown of PE consumption considering renewable and non-renewable share. In the ex-ante scenario, gas for heating service is the main fuel with a non-renewable PE consumption of $228,984.2 \mathrm{kWh}$. Total electricity PE consumption accounts for $130,566.9 \mathrm{kWh}$, where $95,593.6 \mathrm{kWh}$ is renewable and 34,973.3 non-renewable.

The ex-post scenario provides the transition toward electricity with the installation of an electric GSHP. Considering the PE related to electricity consumption, the intervention allows a reduction in total PE consumption of about $57 \%$ with a consumption of $176,743.3$ $\mathrm{kWh}$. Also, in Fig.4, it is reported the non-renewable and renewable PE consumption per energy carrier and the renewable energy rate calculated according to equation (7), that expresses the energy captured by heat pump from the environment. The total renewable PE consumption in the ex-post scenario due to the installation of a GSHP is equal to 297,098.0 $\mathrm{kWh}$, considering the share of electricity from the grid and the renewable component from the environment due to the heat pump. Referring the data, most of the energy consumption is from renewable sources, from the electricity grid and from the environment. Moreover, the renewable component of the heat pump covers $57 \%$ of thermal energy demand for heating and DHW production. Consequently, there is registered a reduction in PE consumption of about $75 \%$ for these services in comparison to the ex-ante scenario, with a total electricity PE consumption of $75,335.9 \mathrm{kWh}$ whereas the overall RER is equal to 0.84 .

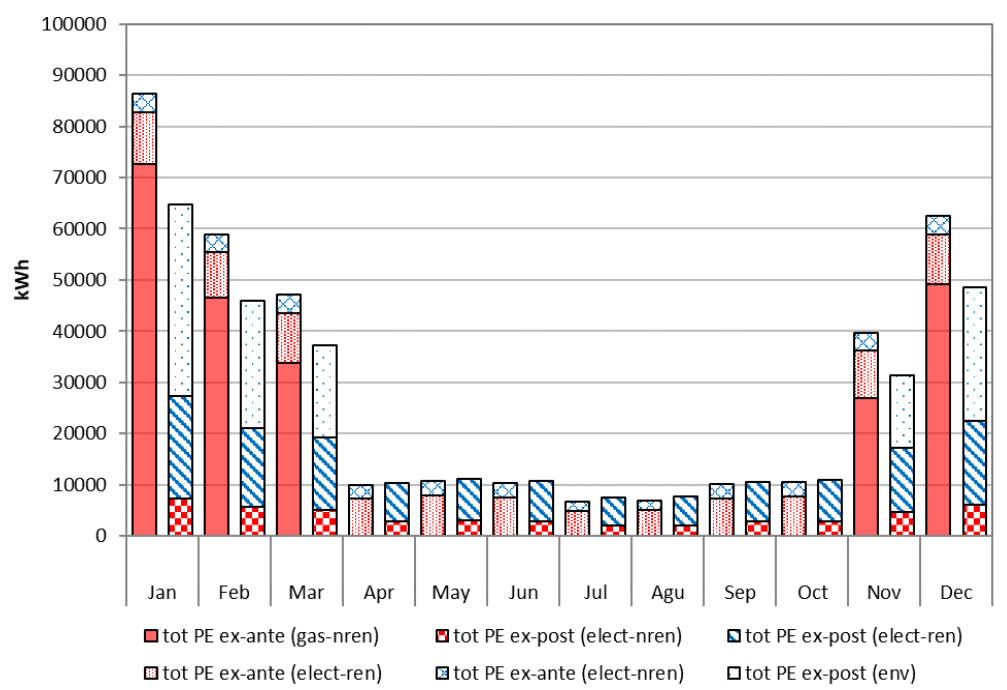

Fig. 4. Comparison of ex-ante and ex-post renewable (blue) and non-renewable (red) PE consumption per energy carrier

The last step involves the comparison of the PE consumption of the reference building in Tirana with the results obtained with the simulation of the same building located in the chosen locations in Foggia (Italy) and Thessaloniki (Greece). In Fig. 5, there are shown the total renewable and non-renewable PE consumption in the selected locations according to the requirements provided by national laws. Total PE consumption in Italy is equal to $212,648.3 \mathrm{kWh}$, where $155,432.8 \mathrm{kWh}$ are non-renewable and $58,735.3 \mathrm{kWh}$ of renewable consumption. The installed PV system produces $25^{\prime} 174.3 \mathrm{kWh}$ per year, covering $85 \%$ of the electricity demand. The remaining $15 \%$ or $3,884.2 \mathrm{kWh}$ is exported to the grid and is 
the overproduction in summer due to the low electric consumption of the building. The RER calculated according to equation (3) is equal to 0.55 . In Greece, where the national law does not specify the type of renewable systems to install and the amount of energy to provide (beside the mandatory coverage of $60 \%$ of DHW production with solar systems), the total PE consumption of this scenario with GSHP is $316,015.0 \mathrm{kWh}$ and the RER 0.33 . To improve the renewable share, it is considered a scenario with PV, with a peak power equal to Italy.

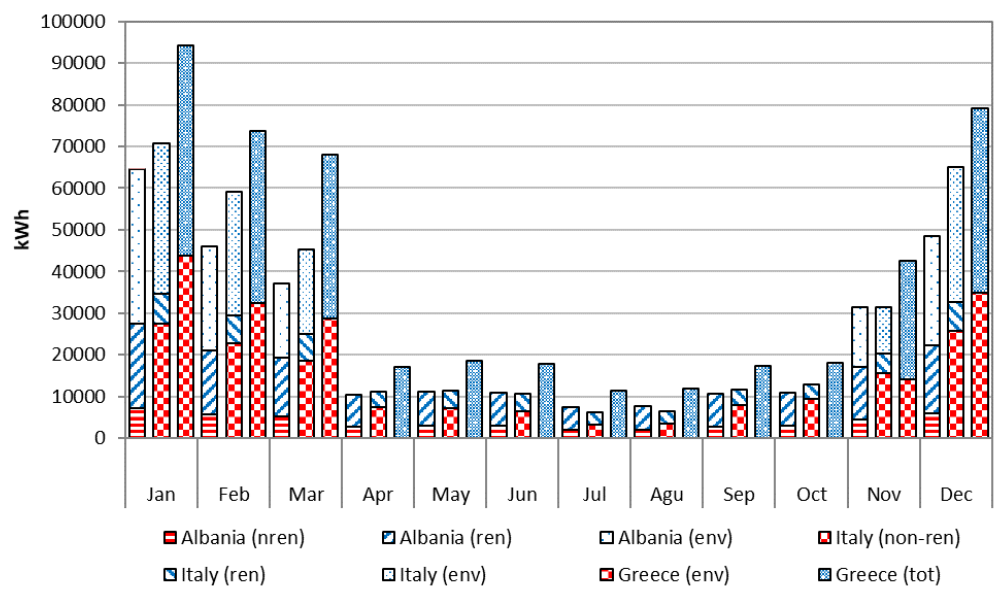

Fig. 5. Comparison of total PE consumption in Albania, Italy and Greece

The PE indicators for the selected countries, referred to total PE consumption and for all scenarios are resumed in Table 6. In Albania, the share of renewable energy is higher due to the high percentage of electricity produced by hydropower stations. Unlike countries with an electricity mix mainly driven by combustible sources where the installation of on-site production systems is mandatory, in Albania it is possible to reach a high-performance target without installing these kinds of systems.

Table 6. PE indicators for the selected countries after refurbishment

\begin{tabular}{|c|c|c|c|c|c|c|c|}
\hline \multirow[t]{2}{*}{ Country } & \multirow[t]{2}{*}{ Scenario } & \multirow{2}{*}{$\begin{array}{c}\text { Delivered } \\
\text { energy } \\
{[\mathbf{k W h}]}\end{array}$} & \multirow{2}{*}{$\begin{array}{c}\text { Onsite } \\
\text { production } \\
{[\mathrm{kWh}]}\end{array}$} & \multicolumn{3}{|c|}{$\begin{array}{c}\text { Total PE consumption } \\
{\left[\mathrm{kWh} / \mathrm{m}^{2} \mathbf{y}\right]}\end{array}$} & \multirow[t]{2}{*}{ RER } \\
\hline & & & & Non-ren & Ren & Tot & \\
\hline Albania & GSHP & 102,172 & - & 41.3 & 218.1 & 259.5 & 0.84 \\
\hline Italy & GSHP + PV & 79,709 & 25,120 & 135.7 & 162.9 & 296.6 & 0.55 \\
\hline \multirow{2}{*}{ Greece } & GSHP & 108,971 & - & - & 134.5 & 410.5 & 0.33 \\
\hline & GSHP + PV & 92,604 & 19,289 & - & 152.2 & 384.8 & 0.40 \\
\hline
\end{tabular}

\section{CONCLUSION}

This study explored the effectiveness of the refurbishment in a nZEB perspective in Albania, considering the local energy market, where electricity is almost produced by hydropower, a renewable energy source. The analysis was carried on the basis of the results of the energy simulation of the building using BEM software, in order to quantify the potential of reaching the nZEB target in Albania, under the local energy market and comparing with other neighbouring countries, Italy and Greece. A limitation of the study is the lack of validation of the energy model due to the absence of monitored real data. Future works will provide a more detailed energy evaluation of the reference building, in order to provide a roadmap for the spread of nZEB in Albania, including economic and environmental evaluation. The current results of the energy simulation highlight that the 
refurbishment in an nZEB perspective of the existing school building can be very advantageous, especially when moving towards technologies powered by electricity, such as GSHP, reducing both primary energy consumption and $\mathrm{CO}_{2}$ emissions. The electricity energy mix of Albania should trigger the diffusion of the refurbishment in an nZEB perspective of buildings because it can lead towards the decarbonisation of the building stock in shorter time than those expected in the 2030 and 2050 climate and energy frameworks, due to the sustainability of the country's grid. Besides these potentialities, it should be noted that Albania is approaching this field recently and other steps are needed to make effective the framework. In this sense, the use of a single U-value for technical components for all climatic zone deserves an examination with a view on the indoor thermal comfort. Further studies will be done in this direction. On the other hand, the technical and economic feasibility of interventions should be explored in terms of availability of technologies and resources and tools identified to promote the refurbishment of the building stock. The intervention on public buildings such as schools has the potential to trigger a debate in the future on the strategy to pursue in Albania for the refurbishment of the existing buildings.

\section{REFERENCES}

1. B. Girod, D.P. van Vuuren, E. G., Hertwich, E. G. Glob. Environ. Change 25 (2014)

2. L. Belussi, B. Barozzi, A. Bellazzi, L. Danza, A. Devitofrancesco, C. Fanciulli, M. Ghellere, G. Guazzi, I. Meroni, F. Salamone, F. Scamoni, C. Scrosati, J. Build. Eng., 100772 (2019)

3. M. Santamouris, M. Sol. Energy 28 (2016)

4. M. Economidou, V. Todeschi, P. Bertoldi, D. D’Agostino, P. Zangheri, L. Castellazzi, Energy and Build., 110322 (2020)

5. D. D'Agostino, L. Mazzarella J. Build. Eng., 21, (2019)

6. B. Atanasiu, J. Maio, J. Staniaszek, I. Koulompi, T. Kenkmann ENTRANZE WP5 report, (2013)

7. https://epbd-ca.eu/ (accessed on 30/10/2020)

8. F. Noris, E. Musall, J. Salom, B. Berggren, S. Jensen, K. Lindberg, I., Sartori, Energy and Build. 82, (2014).

9. M. Hall, A. Geissler, Energy Procedia 122, (2017)

10. K. Dubey, A. Dodonov, United Nations Economic Commission for Europe (2019)

11. Energy Community Secretariat (2019)

12. A. Novikova, Z. Szalay, G. Simaku, T. Thimjo, B. Salamon, T. Plaku, T. Csoknyai, T. SLED (2016)

13. A. Mezősi, L. Szabó, SLED (2015)

14. M. C. Peel, B. L. Finlayson, T. A. McMahon, T. A. (2007). Hydrol. Earth Syst. Sci. 11, 5 (2007)

15. http://climate.onebuilding.org/sources/default.html (accessed on 30/03/2020)

16. Law nr. 537/2020: "Për miratimin e kërkesave minimale të performancës së energjisë së ndërtesave dhe të elementeve të ndërtesave"

17. Interministerial Decree of 26.06.2015: "Applicazione delle metodologie di calcolo delle prestazioni energetiche e definizione delle prescrizioni e dei requisiti minimi degli edifici" 


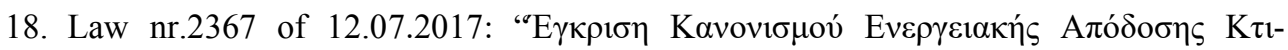

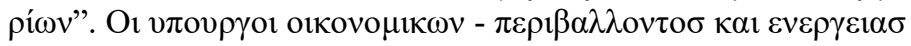

19. U. Rasheed, A. Ibrahim, H. Lee, Preprints (2019)

20. R. Hitchin, Build. Serv. Eng. Res. Technol., 40, 2 (2019)

21. A. Esser, F. Sensfuss, EU (2016)

22. U. R. Fritsche, H. W. Greß, IINAS (2015)

23. R. Tamašauskas, J. Šadauskienè, M. Šadauskaitè, Proceedings 51, 1 (2020)

24. A. Stoffregen, O. Schuller, (2014) 